Agro-Science Journal of Tropical Agriculture, Food, Environment and Extension Volume 21 Number 1 (January 2022) pp. $68-74$

ISSN 1119-7455

\title{
COMPARATIVE STUDY ON THE PHENOLOGY, GENDER AND YIELD COMPONENTS OF CUCUMBER (Cucumis sativus L.) VARIETIES
}

\author{
${ }^{* 1}$ Manggoel W., ${ }^{2}$ Uguru M.I. and ${ }^{2}$ Ogbonna P.E. \\ ${ }^{1}$ Department of Agricultural Technology, College of Agriculture, Garkawa, Plateau, Nigeria \\ ${ }^{2}$ Department of Crop Science, University of Nigeria, Nsukka, Nigeria \\ *Corresponding author's email: wmanggoel@gmail.com
}

\begin{abstract}
The intensity of sex expression is important in crops, including cucumber, since sex form and flowering have direct effects on date of harvesting and yield. Two groups of cucumber comprising a native variety (Odukpani) and elite varieties (Griffaton, Poinsett, Ashley, Marketmore and Monarch) were evaluated in 2015 and 2016 cropping seasons at the Teaching and Research Farm, College of Agriculture, Garkawa, Plateau State; to assess flowering, sex expression and some yield traits. The experimental design was randomized complete block design with the 6 cucumber varieties as the treatments, replicated five times. The two groups differed significantly $(p<0.05)$ in phonological, flowering and yield traits assessed. The elite varieties were superior with respect to flowering traits, as they flowered early. The intra-population hierarchical cluster analysis of quantitative traits grouped the elite varieties in one main cluster and the native variety (Odukpani) alienated as an outlier. The cluster plots showed that Odukpani was robust in vegetative growth, produced few but larger fruit size and flowering was delayed for over two weeks. Conversely, the elite varieties flowered early, produced more flowers and recorded superior number of fruits per plant. The profuse production of pistillate flowers by the elite varieties had pronounced yield advantage over the local variety. Hybridization between the two groups of cucumber would make a mark in the drive for sustainable cucumber fruit yield.
\end{abstract}

Key words: Cucumber, elite varieties, flower ratio, phenology, sex expression

\section{INTRODUCTION}

Cucumber is a popular home garden crop and it is the fourth most cultivated vegetable worldwide (Okonmah, 2011). Its juice is often recommended as sources of silicon to improve the health and complexion of the skin (Duke, 1997). It is a good source of vitamin $\mathrm{A}, \mathrm{C}, \mathrm{K}$, and $\mathrm{B}_{6}$, potassium, pantothenic acids, magnesium, phosphorus, copper and manganese (Vimala et al., 1999). Cucumber is grown for its tender fruits, which are consumed either raw as salad, cooked as vegetable or as pickling in its immature stage (Khan et al., 2015). The optimum dose of poultry manure for growing cucumber in the derived savanna is in the range 20-40 $\mathrm{t} \mathrm{ha}^{-1}$ (Agu et al., 2015; Ogunezi et al., 2019).

Recent findings have contributed to better understanding of sex expression in cucumber and this has inspired research into mechanisms underlying the development, function and evolution of cucumber sex determination and floral morphogenesis (Pawełkowicz et al., 2019). Cucumber is a day neutral annual crop and exhibits a fascinating range of floral morphology, including staminate, pistillate and hermaphrodite flowers which occur in various arrangements (Dalai et al., 2016; Chinatu et al., 2017). Maleness is one of the major problems in cucumber production with attendant significant reduction in fruit yield (Dalai et al., 2016). According to Dey et al. (2005) sex expression of cucumber is determined by genetics as well as environment. Renner et al. (2007) reported that sex expression in the plant is subject to regulation by a number of environmental factors such as photoperiod, temperature and plant hormones. Endogenous levels of auxin and gibberellins determine sex ratio and sequence of flowering (Dey et al., 2005). According to Dalai et al. (2016) optimum doses of growth promoters $\left(\mathrm{GA}_{3}\right.$ and NAA) reduced the male flower initiation. These substances increased functional female organs and compatibility besides reducing the embryo abortion in plants.

The collection and maintenance of crop genetic diversities is important to avoid genetic erosion. It is, therefore, necessary to improve crop yield by finding new sources of useful genes through germplasm collection (Wehner and Cramer, 1996). Several elite varieties of cucumber have been released in developed countries. These exotic varieties possess important qualitative and quantitative traits such as early flowering, gynoecy, fruit quality and yield traits (Kumar et al., 2013; Khan et al., 2015; Ranjian et al., 2015; Dalai et al., 2016; Chinatu et al., 2017; Pal et al., 2017; Sadiq et al., 2019). But farmers encounter some challenges in the use of the elite varieties as planting materials because of poor adaptation. They are vulnerable to both biotic and abiotic stresses which often culminate into poor pod yield (Strefeler and Wehner, 1986). 
Cucumber field evaluation by most scholars (Airina et al., 2013; Kumar et al., 2013; Pati et al., 2015; Dalai et al., 2016; Sadiq et al., 2019) used improved elite varieties; thus, the preservation of bio-diverse indigenous crops is left in the hands of traditional agricultural practice. This has led to the extinction of many important landraces and indigenous (native) varieties (Uguru, 1998). The knowledge of genetic diversities of indigenous (native) crops vis-à-vis imported elite varieties is important to ensure germplasm conservation and improvement. On this premise, the present study was initiated to evaluate native and elite cucumber varieties with a view to establishing their phenological, flowering and yield differences.

\section{MATERIALS AND METHODS}

\section{Location of the Experimental Site}

The experiments were carried out at the Teaching and Research Farm of College of Agriculture, Garkawa, Plateau State, Nigeria in 2015 and 2016 cropping seasons. The area lies at latitude $9^{\circ} 55^{\prime} \mathrm{N}$ and longitude $8^{\circ} 35^{\prime} \mathrm{E}$ in the Southern Guinea Savanna zone of Nigeria. The climate is characterized by two distinct wet and dry seasons. The wet season starts in April and ends in October while the dry season starts in November and ends in March. The meteorological data for the period of the research (2015 and 2016) is presented (Table 1). The total amounts of rainfall for the period of study were 1791.3 and $1377.3 \mathrm{~mm}$ for 2015 and 2016, respectively. The mean temperatures for 2015 and 2016 were 28.1 and $28.0^{\circ} \mathrm{C}$ and the relative humidity were $53.2 \%$ and $53.1 \%$, respectively.

\section{Experimental Materials}

The materials for the research comprised five elite cucumber varieties and one indigenous variety from Odukpani in Cross River State, Nigeria. The elite varieties are Griffaton, Poinsett, Ashley, Marketmore and Monarch. The passport data of the cucumber varieties used in the field trial is presented (Table 2).

\section{Field Preparation and Experimental Design}

The land was ploughed, harrowed and ridged using tractor mounted disc plough, harrow, and ridger, respectively. Planting was done in April, 2015 and 2016 using intra- and inter-row spacing of $1.0 \times$ $0.75 \mathrm{~m}$. The plot size was $2 \times 4 \mathrm{~m}\left(8 \mathrm{~m}^{2}\right)$ giving a plant population of 16 per plot. The experimental design was randomized complete block design, with the six cucumber varieties as treatments replicated five times. The distance between blocks was $1 \mathrm{~m}$. Weed control was done by manual weeding using small hoe. To achieve optimum fruit yield, NPK 15:15:15 fertilizer was applied at the rate of $120 \mathrm{~kg} \mathrm{ha}^{-1}$ in two equal split doses at the time of seed sowing and before flowering as recommended by Iwalewa and Amujoyegbe (2019).

\section{Data Collection}

The data collected comprised number of leaves per plant $(\mathrm{NL} / \mathrm{P})$, number of branches per plant $(\mathrm{NB} / \mathrm{P})$, vine length (VL), days to first flowering (DFF), days to $50 \%$ flowering $(\mathrm{D} 50 \% \mathrm{~F})$, number of staminate flowers per plant $(\mathrm{NSF} / \mathrm{P})$, number of pistillate flowers per plant (NPF/P), days to first fruit (DFFr), days to $50 \%$ fruiting $(\mathrm{D} 50 \% \mathrm{Fr})$, fruit girth (FG), fruit length (FL), average fruit weight (AFW) and number of fruits per plant $(\mathrm{NFr} / \mathrm{P})$. The numbers of leaves per plant, number of primary branches per plant and vine length measurements were taken at two weekly intervals, starting at 2 weeks after planting. The number of leaves and number of branches were obtained by counting and the vine length was determined by measuring the vine with a flexible measuring tape from the base above the soil level to the tip of the primary vine. Days to first flowering was recorded as the number of days from sowing to first flower production and days to $50 \%$ flowering was obtained as the number of days from sowing to when $50 \%$ of the plants flowered. The number of male and female flowers per plant was counted daily from the onset to the end of reproductive phase. The ratio of the staminate to pistillate flowers was obtained by dividing the mean number of staminate flowers by the mean number of pistillate flowers produced by each variety. Fruit length and girth were measured at harvest using flexible measuring tape. The number of fruits per plant was determined by dividing the total number of fruits in a plot by the total number of plants in the plot. Fruit weight was taken using an electronic weighing balance.

Table 1: Meteorological data covering the experimental period in 2015 and 2016

\begin{tabular}{lccc} 
period in 2015 and 2016 & & \\
& $\begin{array}{c}\text { Rainfall } \\
(\mathrm{mm})\end{array}$ & $\begin{array}{c}\text { Mean monthly } \\
\text { temperature }\left({ }^{\circ} \mathrm{C}\right)\end{array}$ & $\begin{array}{c}\text { \%Mean monthly } \\
\text { rel. humidity }\end{array}$ \\
\hline 2015 & & & \\
April & 41.7 & 32.4 & 52 \\
May & 61.9 & 30.3 & 62 \\
June & 171.0 & 27.8 & 71 \\
July & 569.0 & 25.9 & 77 \\
August & 707.0 & 24.7 & 69 \\
September & 126.0 & 26.8 & 49 \\
October & 114.7 & 28.5 & 23 \\
November & 0.0 & 30.1 & 33 \\
December & 0.0 & 26.3 & 479.0 \\
Total & 1791.3 & 252.8 & 53.22 \\
Mean & 199.03 & 28.09 & \\
2016 & & & 41 \\
April & 17.4 & 32.6 & 57 \\
May & 170.5 & 29.7 & 61 \\
June & 253.0 & 28.5 & 69 \\
July & 347.0 & 26.9 & 72 \\
August & 376.6 & 26.0 & 71 \\
September & 197.6 & 26.6 & 54 \\
October & 15.2 & 28.8 & 33 \\
November & 0.0 & 28.6 & 20 \\
December & 0.0 & 24.4 & \\
Total & 1377.3 & 252.1 & \\
Mean & 153.03 & 28.01 & \\
\hline & & & \\
\hline
\end{tabular}


Table 2: Passport data of native and elite cucumber varieties used for the research

\begin{tabular}{lll}
\hline Variety & Source of seed & Description \\
\hline Odukpani & Odukpani, Cross River State & Unimproved local variety \\
Griffaton & Jos, Plateau (Imported: Cucumber Breeding Station, *NCSU, USA) & Elite (Exotic) variety \\
Poinsett & Jos, Plateau (Imported: Cucumber Breeding Station, NCSU, USA) & Elite (Exotic) variety \\
Ashley & Jos, Plateau (Imported: Cucumber Breeding Station, NCSU, USA) & Elite (Exotic) variety \\
Marketmore & Jos, Plateau (Imported: Cucumber Breeding Station, NCSU, USA) & Elite (Exotic) variety \\
Monarch & Jos, Plateau (Imported: Cucumber Breeding Station, NCSU, USA) & Elite (Exotic) variety \\
\hline
\end{tabular}

*NCSU is North Carolina State University

\section{Data Analysis}

Data were analyzed using GenStat (2011) and significant treatment means were separated using the least significant difference (LSD) at $5 \%$ probability level (Obi, 2002). Principal component analysis was performed (Manly, 1994; Johnson, 1998) to establish the degree of variability among the cucumber varieties. Hierarchical clustering was also carried out to classify the cucumber varieties based on squared Euclidean distances (Johnson, 1998).

\section{RESULTS}

\section{Flowering Traits}

Varietal differences between the native Odukpani and elite cucumber varieties in flowering traits for the two cropping seasons are shown (Tables 3 and 4 ). The cucumber varieties significantly $(p<0.05)$ differed in all the flowering traits assessed. There were no significant differences between the two cropping years and the variety by year interaction.
On this premise, the mean values were averaged over the two cropping years. The mean days to first and $50 \%$ flowering ranged from 30.0 to 46.5 days and 32.5 to 51.5 days, respectively. Days to first flowering in the Odukpani variety was significantly $(p<0.05)$ delayed when compared to the elite varieties. Days to $50 \%$ flowering followed the same trend as the native Odukpani took longer time ( 51.5 days) to attain days to $50 \%$ flowering compared to the elite varieties (32.5 to 34.5 days) (Table 3 ).

The mean NSF/P and NPF/P values ranged from 128.8 to 195.4 and 25.0 to 45.7 , respectively (Table 4). The elite varieties were prolific in the production of male (165-195 per plant) and female flowers (37-43 per plant). The native Odukpani had relatively lower male (128.8) and female (25) flowers. The ratio of the staminate to pistillate flowers differed significantly and was low in the elite varieties (3.9-4.5) and higher in the native Odukpani variety (5.1) (Figure 1).

Table 3: Differences between native and elite varieties of cucumber in days to flowering in two cropping seasons

\begin{tabular}{|c|c|c|c|c|c|c|}
\hline \multirow[t]{2}{*}{ Parents } & \multicolumn{3}{|c|}{ Days to first flowering } & \multicolumn{3}{|c|}{ Days to $50 \%$ flowering } \\
\hline & 2015 & 2016 & Mean & 2015 & 2016 & Mean \\
\hline Odukpani & 45.6 & 47.4 & 46.5 & 50.6 & 52.4 & 51.5 \\
\hline Griffaton & 29.0 & 31.6 & 30.3 & 32.7 & 34.3 & 33.5 \\
\hline Poinsett & 31.5 & 28.5 & 30.0 & 32.9 & 32.1 & 32.5 \\
\hline Ashley & 29.2 & 31.8 & 30.5 & 32.9 & 33.1 & 33.0 \\
\hline Marketmore & 30.5 & 32.5 & 31.5 & 31.8 & 35.2 & 33.5 \\
\hline Monarch & 31.5 & 31.7 & 31.6 & 33.6 & 35.4 & 34.5 \\
\hline Mean & 32.88 & 33.92 & & 35.75 & 37.08 & \\
\hline \multicolumn{7}{|l|}{$\operatorname{LSD}(p<0.05)$} \\
\hline Genotype (g) & & & 1.53 & & & 2.68 \\
\hline Year (y) & & & NS & & & NS \\
\hline$g \times y$ & & & NS & & & NS \\
\hline
\end{tabular}

NS - not significant

Table 4: Differences in sex expression between native and elite cucumber varieties in two cropping seasons

\begin{tabular}{|c|c|c|c|c|c|c|}
\hline \multirow[t]{2}{*}{ Parents } & \multicolumn{3}{|c|}{ Number of staminate flowers per plant } & \multicolumn{3}{|c|}{ Number of pistillate flowers per plant } \\
\hline & 2015 & 2016 & Mean & 2015 & 2016 & Mean \\
\hline Odukpani & 126.9 & 130.7 & 128.8 & 26.5 & 24.5 & 25.0 \\
\hline Griffaton & 168.6 & 170.4 & 169.5 & 42.7 & 43.9 & 43.3 \\
\hline Poinsett & 165.4 & 166.0 & 165.7 & 40.0 & 39.4 & 39.7 \\
\hline Ashley & 182.1 & 183.5 & 183.3 & 39.6 & 41.0 & 40.3 \\
\hline Marketmore & 196.2 & 194.6 & 195.4 & 44.6 & 46.8 & 45.7 \\
\hline Monarch & 166.6 & 168.0 & 167.3 & 37.2 & 39.6 & 38.4 \\
\hline Mean & 176.80 & 177.70 & & 38.43 & 39.20 & \\
\hline \multicolumn{7}{|l|}{$\operatorname{LSD}(p<0.05)$} \\
\hline Genotype (G) & & & 21.51 & & & 2.63 \\
\hline Year (Y) & & & NS & & & NS \\
\hline$G \times Y$ & & & NS & & & NS \\
\hline
\end{tabular}




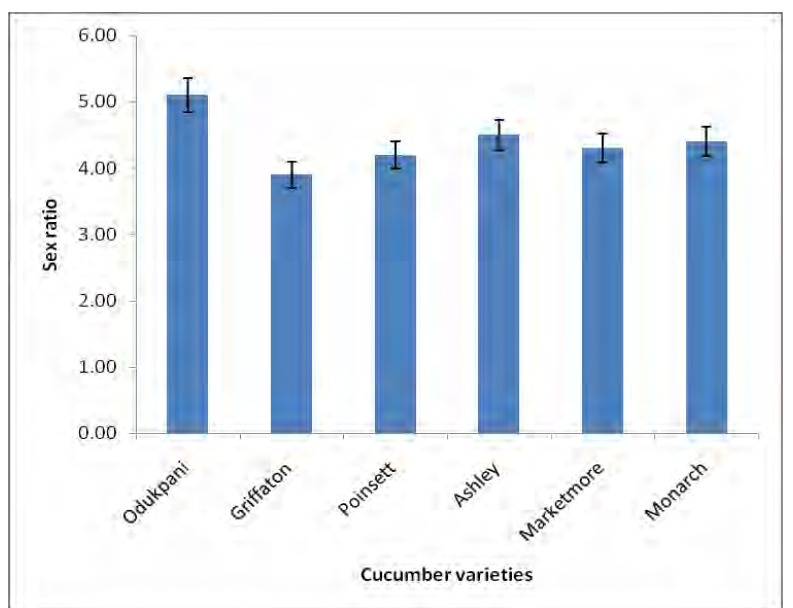

Figure 1: Scattered diagram of first two principal components based on mean values of 13 quantitative traits among 6 cucumber varieties

\section{Yield Traits}

The differences between the cucumber varieties were significant $(p<0.05)$ for the vegetative traits assessed (Table 5). The mean values for NL/P, $\mathrm{NB} / \mathrm{P}$ and VL were in the ranges of 107.6-280.3, 9.5-23.5 and 101.3-296.9 $\mathrm{cm}$, respectively. Odukpani variety recorded significantly higher $(p<0.05)$ mean values for NL/P (280), NB/P (24) and VL $(296.9 \mathrm{~cm})$ compared to the elite varieties. Mean values of NL/P and VL also differed significantly among the elite varieties of cucumber, with Griffaton (NL/P, 175; VL, $155.1 \mathrm{~cm})$ and Marketmore (NL/P, 168; VL, $167.4 \mathrm{~cm}$ ) being more prolific in leaf production and vine length than the other elite varieties (Table 5).
Varietal differences between the native accession (Odukpani) and elite cucumber varieties in some fruit traits for the two cropping seasons are presented in Table 6 . The cucumber varieties differed significantly $(p<0.05)$ for all the fruit traits, except FL. There was however no significant difference between the two cropping years, as well as the variety $\times$ year interaction. Mean values for fruit girth (FG) ranged from $5.9 \mathrm{~cm}$ for Marketmore to $7.5 \mathrm{~cm}$ for Odukpani. Average fruit weight for the cucumber varieties evaluated ranged from 321.7-630.1 g per fruit. Odukpani had significantly higher $(p<0.05)$ fruit weight than those of the elite varieties. However, Odukpani recorded lower number of fruits per plant compared to those of the elite varieties. The variety, Griffaton, produced the highest number of fruits per plant (15.7) (Table 6).

\section{Principal Component Analysis (PCA)}

The result of the principal component analysis for the six cucumber varieties averaged over two cropping seasons (2015 and 2016) is presented in Table 7. The first three principal component (PC) axes contributed a total of $97.89 \%$ of the total variability among the varieties evaluated. The PC1, PC2 and PC3 accounted for 81.13, 10.19 and $6.57 \%$ of the total variations, respectively. The contribution of the traits towards the diversity among the cucumber varieties revealed that in the first principal component axis, the traits with the highest loadings were number of leaves per plant, vine length, number of branches per plant, days to first flowering, days to $50 \%$ flowering, days to first fruiting, days to $50 \%$ fruiting, number of staminate

Table 5: Differences between native and elite cucumber varieties for selected vegetative traits ( 8 weeks after planting) in 2015 and 2016 cropping seasons

\begin{tabular}{|c|c|c|c|c|c|c|c|c|c|}
\hline \multirow[t]{2}{*}{ Parents } & \multicolumn{3}{|c|}{ Number of leaves per plant } & \multicolumn{3}{|c|}{ Number of branches per plant } & \multicolumn{3}{|c|}{ Vine length $(\mathrm{cm})$} \\
\hline & 2015 & 2016 & Mean & 2015 & 2016 & Mean & 2015 & 2016 & Mean \\
\hline Odukpani & 281.1 & 279.5 & 280.3 & 24.6 & 22.4 & 23.5 & 294.0 & 299.8 & 296.9 \\
\hline Griffaton & 173.2 & 176.6 & 174.9 & 9.2 & 9.8 & 9.5 & 156.5 & 153.7 & 155.1 \\
\hline Poinsett & 105.8 & 109.4 & 107.6 & 10.6 & 11.4 & 11.0 & 99.2 & 103.4 & 101.3 \\
\hline Ashley & 121.3 & 129.5 & 125.4 & 9.8 & 11.2 & 10.5 & 138.4 & 144.0 & 141.2 \\
\hline Marketmore & 157.5 & 177.9 & 167.7 & 13.1 & 15.9 & 14.5 & 169.3 & 165.1 & 167.4 \\
\hline Monarch & 144.6 & 142.2 & 143.4 & 8.4 & 10.8 & 9.6 & 151.1 & 153.2 & 152.3 \\
\hline Mean & 163.92 & 169.18 & & 13.3 & 13.58 & & 168.08 & 169.87 & \\
\hline $\operatorname{LSD}(p<0.05)$ & & & & & & & & & \\
\hline Genotype (G) & & & 23.01 & & & 1.20 & & & 11.42 \\
\hline Year (Y) & & & NS & & & NS & & & NS \\
\hline $\mathrm{G} \times \mathrm{Y}$ & & & NS & & & NS & & & $\mathrm{NS}$ \\
\hline
\end{tabular}

Table 6: Differences between native and elite cucumber varieties for fruits traits in two cropping seasons (2015 and 2016)

\begin{tabular}{|c|c|c|c|c|c|c|c|c|c|c|c|c|}
\hline \multirow[t]{2}{*}{ Parents } & \multicolumn{3}{|c|}{ Fruit length $(\mathrm{cm})$} & \multicolumn{3}{|c|}{ Fruit girth $(\mathrm{cm})$} & \multicolumn{3}{|c|}{ Average fruit weight $(\mathrm{g})$} & \multicolumn{3}{|c|}{ Number of fruits per plant } \\
\hline & 2015 & 2016 & Mean & 2015 & 2016 & Mean & 2015 & 2016 & Mean & 2015 & 2016 & Mean \\
\hline Odukpani & 19.6 & 20.2 & 19.9 & 7.2 & 7.8 & 7.5 & 625.6 & 634.6 & 630.1 & 10.0 & 10.6 & 10.3 \\
\hline Griffaton & 22.6 & 22.8 & 22.7 & 6.8 & 7.0 & 6.9 & 530.6 & 527.4 & 529.0 & 14.6 & 16.8 & 15.7 \\
\hline Poinsett & 21.8 & 22.0 & 21.9 & 6.8 & 6.8 & 6.8 & 355.4 & 365.0 & 360.2 & 12.0 & 12.6 & 12.3 \\
\hline Ashley & 21.7 & 22.1 & 21.9 & 5.9 & 7.4 & 6.6 & 439.2 & 437.6 & 438.4 & 12.5 & 12.9 & 12.7 \\
\hline Marketmore & 20.5 & 20.9 & 20.7 & 5.8 & 6.0 & 5.9 & 320.2 & 322.5 & 321.7 & 13.6 & 15.2 & 14.4 \\
\hline Monarch & 21.7 & 21.5 & 21.6 & 6.8 & 6.6 & 6.7 & 403.1 & 418.7 & 410.9 & 10.8 & 13.0 & 11.9 \\
\hline Mean & 21.32 & 21.58 & & 6.55 & 6.93 & & 409.7 & 450.97 & & 12.25 & 13.52 & \\
\hline $\operatorname{LSD}(p<0.05)$ & & & & & & & & & & & & \\
\hline Genotype (G) & & & NS & & & 0.24 & & & 88.02 & & & 0.98 \\
\hline Year (Y) & & & NS & & & NS & & & NS & & & NS \\
\hline $\mathrm{G} \times \mathrm{Y}$ & & & NS & & & NS & & & NS & & & NS \\
\hline
\end{tabular}

NS - not significant 
Table 7: Eigen values, variance and component scores of the first three principal components (PC) for 13 quantitative traits among six cucumber varieties

\begin{tabular}{lccc}
\hline Traits & PC1 & PC2 & PC3 \\
\hline Number of leaves per plant & 0.28375 & 0.01952 & -0.40440 \\
Vine length (cm) & 0.29311 & -0.05206 & -0.27606 \\
Number of branches per plant & 0.28863 & -0.23897 & -0.12880 \\
Days to first flowering & 0.30746 & -0.04181 & -0.01536 \\
Days to 50\% flowering & 0.30780 & 0.00814 & -0.01220 \\
Days to first fruit & 0.30724 & -0.01777 & -0.00913 \\
Days to 50\% fruiting & 0.30713 & -0.01095 & 0.01726 \\
Number of staminate flowers per plant & -0.29051 & -0.19140 & -0.06181 \\
Number of pistillate flowers per plant & -0.28738 & 0.13114 & -0.15269 \\
Fruit length (cm) & -0.23876 & 0.54792 & 0.02217 \\
Fruit girth (g) & 0.22092 & 0.54638 & 0.31327 \\
Average fruit weight (g) & 0.23932 & 0.51046 & -0.18326 \\
Number of fruits per plant & -0.20542 & 0.15623 & -0.76390 \\
Variance (\%) & 81.13 & 10.19 & 6.57 \\
Cumulative variance (\%) & 81.13 & 91.32 & 97.89 \\
\hline
\end{tabular}

flowers per plant and number of pistillate flowers per plant. The second principal component axis weighed highest in fruit length, fruit girth and average fruit weight. The third principal component axis loaded high for number of fruits per plant.

The dendrogram of the hierarchical cluster analysis conducted on the yield traits separated the elite varieties in one cluster and isolated the native variety as an outlier (Figure 2). The first two principal components were plotted to observe the relationship among the six cucumber varieties (Figure 3). The varieties were found to be clustered together, while Odukpani was a separate cluster (a singleton) as also observed in the cluster analysis.
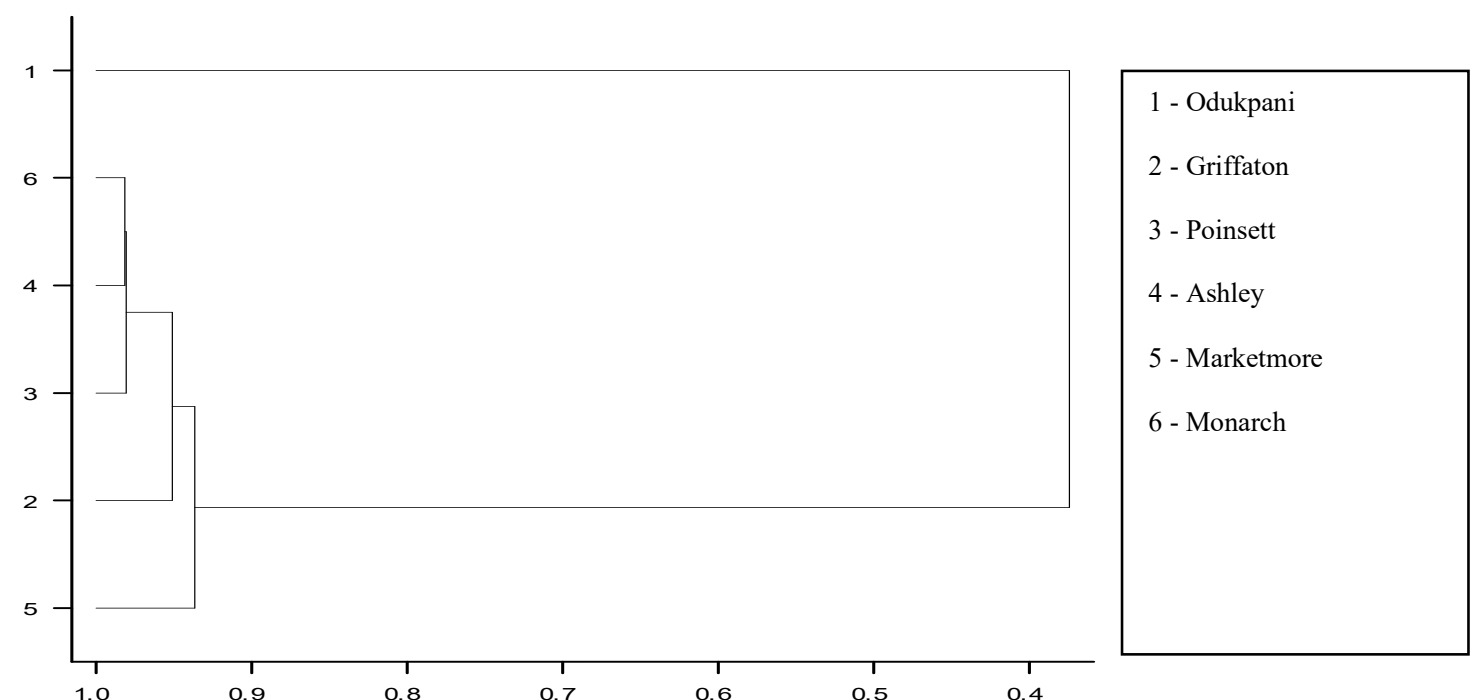

Figure 2: Dendrogram based on squared Euclidean distances analysis showing genetic relationship among cucumber varieties

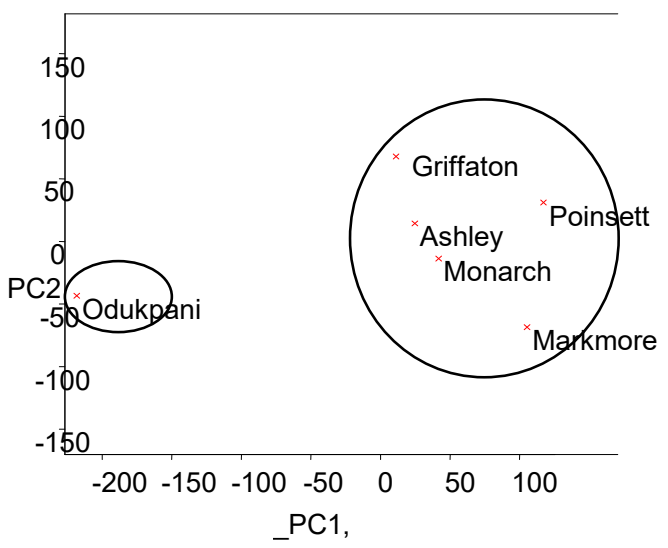

Figure 3: Scattered diagram of first two principal components based on mean values of 13 quantitative traits among 6 cucumber varieties
The cluster mean values for the 13 yield traits for the cucumber varieties average over the two cropping years are presented in Table 8 . The cluster means showed that the main cluster comprised the early flowering elite varieties, having cluster means of 30.8 days (DFF) and 33.4 days $(\mathrm{D} 50 \% \mathrm{~F})$. The elite varieties recorded higher cluster mean for number of staminate flowers per plant (176.2), number pistillate flowers per plant (41.5) and number of fruits per plant (13.4). Odukpani was, however, late flowering (DFF was 46.5 days; $\mathrm{D} 50 \% \mathrm{~F}$ was 51.5 days) and distinct as an outlier. This variety also recorded higher values for vegetative traits (NL/P, 280.3; NB/P, 23.5; VL, $296.9 \mathrm{~cm}$ ), as well as for fruit girth $(7.5 \mathrm{~cm})$ and fruit weight per plant $(630.1 \mathrm{~g})$ as shown in Table 8. 
Table 8: Cluster means for 13 yield traits for native and elite cucumber varieties averaged over two cropping seasons (2015 and 2016)

\begin{tabular}{llc}
\hline Traits & $\begin{array}{r}\text { Elite varieties } \\
\text { (Main cluster) }\end{array}$ & $\begin{array}{c}\text { Native variety } \\
\text { (Outlier) }\end{array}$ \\
\hline Number of leaves per plant & 143.8 & 280.3 \\
Number of branches per plant & 11.0 & 23.5 \\
Vine length (cm) & 143.5 & 296.9 \\
Days to first flowering & 30.8 & 46.5 \\
Days to 50\% flowering & 33.4 & 51.5 \\
Number of staminate & 176.2 & 128.8 \\
flowers per plant & & \\
Number of pistillate & 41.5 & 25.0 \\
flowers per plant & & \\
Days to first fruit & 35.9 & 56.5 \\
Days to 50\% fruiting & 37.8 & 62.5 \\
Fruit length (cm) & 21.8 & 19.9 \\
Fruit girth (g) & 6.6 & 7.5 \\
Average fruit weight (g) & 412.0 & 630.1 \\
Number of fruits per plant & 13.4 & 10.3 \\
\hline
\end{tabular}

\section{DISCUSSION}

Earliness in crop production is an important agronomic trait since it has been reported to provide the advantage of opening the possibility of successful sole cropping in areas with short rainy season as well as encourages double/triple cropping systems (Adeyanju and Ishiyaku, 2007). If the genetic basis of early and continuous flowering is understood, it can be exploited in the development of crop varieties that can flower and fruit continually thereby ensuring all year-round availability of cucumber for the teaming population in sub-Saharan Africa. The wide gap in days to flowering between the native and elite cucumber varieties is a reflection of differences associated with the two groups with respect to earliness. This finding is consistent with the report of Afangideh and Uyoh (2007) who documented in the rain forest area of Calabar, Nigeria that days to flowering for eleven exotic varieties were shorter compared to those of six indigenous cultivars.

The intensity of sex expression is important in cucumber, since sex and flowering have direct effect on date of harvesting and productivity of the crop (Pati et al., 2015). The development of female flowers is also an important process that directly affects fruit yield and quality of cucumber (Pan et al., 2018). The prolific production of flowers by the elite varieties in this study implied high reproductive efficiency as they are suitable candidates for obtaining gynoecious hybrids. The lower sex ratio (staminate to pistillate flowers) recorded for the elite varieties suggest innate tendencies for the suppression of staminate flowers and increase in the number of pistillate flowers. The value for sex ratio obtained in this study (3.9-4.5) for the elite varieties is similar to the value (3.81) reported by Dalai et al. (2016) for the control treatment (zero application) when the authors used growth regulators $\left(\mathrm{GA}_{3}\right.$ and NAA) to study flowering, yield and yield contributing parameters in cucumber.
The high mean values for number of leaves per plant, number of branches per plant and vine length recorded by the indigenous Odukpani imply that the variety is superior in vegetative growth and these morphometric traits could be harnessed by breeders for higher reproductive output. Contrary to this report, Iwalewa and Amujoyegbe (2019), Chinatu et al. (2017) and Afangideh and Uyoh (2007) reported superior vegetative performance for Marketmore and Ashley.

The significant differences in fruit traits implied that the traits had significant contributions towards diversity among the genotypes evaluated. The greater diversity in the present materials is due to the yield characters which could offer a promising base for improvement of the fruit yield through selection from the parental lines. The average fruit weights of the elite varieties reported here were within the range reported for 12 hybrids by Airina et al. (2013). The mean number of fruits produced by the elite varieties are within the range for some cucumber varieties (Ashley, Marketmore and Griffaton) reported by Iwalewa and Amujoyegbe (2019), Chinatu et al. (2017), Adesina and Benjamin (2016) and Eifediyi and Remison (2010). However, significantly higher total fruit yield has been reported for six indigenous cultivars by Afangideh and Uyoh (2007).

The main reason for plant collection is to obtain natural variability that could be useful for providing germplasm pools for crop improvement. Principal component analysis (PCA) is, perhaps, the most useful statistical tool for screening multivariate data (Johnson, 1998). Information obtained through PCA could assist plant breeders to identify a limited number of highly differentiated populations for use in hybridization and selection programmes. All the traits used in the study fully captured the variation in the varieties studied. The intra-population variability evaluated by hierarchical cluster analysis grouped the cucumber varieties into one main elite cluster and an outlier (Odukpani), indicating appreciable variability between the native and elite cucumber varieties to warrant selection. The main cluster comprised of the elite varieties: Griffaton, Poinsett, Ashley, Marketmore and Monarch. The native variety was alienated from the main cluster which suggests that the accession is genetically dissimilar to the elite cucumber varieties. The cluster means showed that the native Odukpani was robust in vegetative growth, had maximum staminate: pistillate flower ratio, produced few but large fruit sizes and late flowering. Comparatively, the elite cluster varieties were early flowering, produced more pistillate flowers (gynoecious sex expression) and recorded high number of fruits per plant. The selection of superior genotypes within the view point of desirable phenological, flowering, gender and yield traits, with high genetic distance, as observed in this study would assist in hybridization programs to produce high yielding hybrids in cucumber. 


\section{CONCLUSION}

The study confirmed that the two groups of cucumber (native and elite) varieties are genetically dissimilar and distantly related. The native variety (Odukpani) was alienated from the main cluster which suggests that the accession is genetically dissimilar to the elite cucumber varieties. It was robust in vegetative traits assessed, produces few but very large fruit sizes and flowered late. The elite varieties (Griffaton, Poinsett, Ashley, Marketmore and Monarch), on the other hand, were early flowering, produced more pistillate flowers and recorded high number of fruits per plant. The production of hybrids between the two groups will provide planting materials with superior fruit yield for commercial production of cucumber.

\section{REFERENCES}

Adesina J.M. and Benjamin A.T. (2016). Varietal productivity and planting date effect on the growth and yield of cucumber (Cucumis sativus L.) in Owo, Southwestern Nigeria. Int. J. Hort., 6 (23), 1-9

Adeyanju A.O. and Ishiyaku M.F. (2007). Genetic study of earliness in cowpea cowpea (Vigna unguiculata L. Walp) under screen house condition. Int. J. Plant Breed. Genetics, 1, 34-37

Afangideh U. and Uyoh E.A. (2007). Genetic variability and correlation studies in some varieties of cucumber (Cucumis sativus L.). Jordan J. Agric. Sci., 3 (4), 376-384

Agu R.S., Ezema R.A., Udegbunam O.N. and Okoro A.C. (2015). Effect of different rates of poultry manure on growth and yield of cucumber (Cucumis sativum) in Iwollo, Southeastern Nigeria. Agro-Sci., 14 (3), 41-44

Airina C.K., Pradeepkumar T., George T.E., Sadhankumar P.G. and Krishnan S. (2013). Heterosis breeding exploiting gynoecy in cucumber (Cucumis sativus L.). J. Trop. Agric., 5 (1-2), 144-148

Chinatu L.N., Onwuchekwa-Henry C.B. and Okoronkwo C.M. (2017). Assessment of yield and yield components of cucumber (Cucumis sativus L.) in Southeastern Nigeria. Int. J. Agric. Earth Sci., 3 (1), 35-44

Dalai S., Singh M.K., Kumar M., Singh K.V. and Kumar V. (2016). Growth, flowering and yield of cucumber (Cucumis sativus L.) as influenced by different levels of NAA and $\mathrm{GA}_{3}$. J. Plant Dev. Sci., 8 (9), 445-450

Dey S.S., Batters T.K., Pal A. and Munshi A.D. (2005). Correlation and path coefficient analysis in bitter gourd (Momordica charantia L.). Veg. Sci., 32, 173-176

Duke S. (1997). The Green Pharmacy. New York: St. Martins Press, p. 351

Eifediyi E.K. and Remison S.U. (2010). Growth and yield of cucumber (Cucumis sativus L.) as influenced by farm yard manure and inorganic fertilizer. J. Plant Breed. Crop Sci., 2 (7), 216-220

GenStat (2011). Genstat Discovery (10th ed.), version 10.3, VSN international Ltd, www.vsni.co.uk

Iwalewa E.A. and Amujoyegbe B.J. (2019). Influence of fertilizer types and rates on the growth and fruit yield of three cucumber (Cucumis sativus L.) varieties. Ife J. Agric., 31 (3), 36-49

Johnson D.E. (1998). Applied Multivariate Methods for Data Analysis. New York: Duxbury Press

Khan Z., Shah A.H., Gul R., Majid A., Khan U. and Ahmad H. (2015). Morpho-agronomic characterization of cucumber germplasm for yield and yield associated traits. Int. J. Agron. Agric. Res., 6 (1), 1-6
Kumar S., Kumar D., Kumar R., Thakur K.S. and Dogra B.S. (2013). Estimation of genetic variability and divergence for fruit yield and quality traits in cucumber (Cucumis sativus L.) in Northwestern Himalayas. Univer. J. Plant Sci., 1 (2), 27-36

Manly B.F.J. (1994). Multivariate Statistical Methods. New York: Champman and Hall

Obi I.U. (2002). Statistical Methods of Detecting Differences Between Treatment Means and Research Methodology Issues in Laboratory and Field Experiments. Nsukka: AP Express Publishers Ltd

Ogunezi K.C., Okebalama C.B. and Obalum S.E. (2019). Optimum poultry droppings rate for coarse-loamy Ultisols based on soil macro-aggregation and fertility indices and evaluation using cucumber (Cucumis sativus). Presented under Understanding Nigerian Soils for Sustainable Food \& Nutrition Security and Healthy Environment, 43rd Ann. Conf. Soil Sci. Soc. Nig. (SSSN), 15-19 Jul. 2019, University of Agriculture, Makurdi, Benue State, Nigeria

Okonmah L.U. (2011). Effects of different types of staking and their cost effectiveness on the growth, yield and yield components of cucumber (Cucumis sativus L.). J. Agric. Sci., 1 (5), 290-295

Pal S., Rahj H. and Yadav S.N. (2017). Evaluation of cucumber genotypes for yield and quality traits. $J$. Hill Agric., 8 (2), 144-150

Pan J., Wang G., Wen H., Du H., Lian H., He H., Pan J. and Cai R. (2018). Differential gene expression caused by the $F$ and $M$ loci provides insight into ethylene-mediated female flower differentiation in cucumber. Front. Plant Sci., 9, 1091. https://doi.org/10.3389/fpls.2018.01091

Pati K., Das-Munshi A. and Kanti-Behera T. (2015). Inheritance of gynoecism in cucumber (Cucumis sativus L.) using genotype gbs-1 as gynoecious parent. Genetika, 47 (1), 349-356

Pawełkowicz M.E., Skarzyńska A., Pląder W. and Przybecki Z. (2019). Genetic and molecular bases of cucumber (Cucumis sativus L.) sex determination. Molecular Breeding, 39 (50), 1-27

Ranjian P., Gangopadhyay K., Bag M.K. and Roy A. (2015). Evaluation of cucumber (Cucumis sativus) germplasm for agronomic traits and disease resistance and estimation of genetic variability. Indian J. Agric. Sci., 85 (2), 234-239

Renner S.S., Schaefer H. and Kocyan A. (2007). Phylogenetics of cucumis (cucurbitaceae): Cucumber (C. sativus) belongs in an Asian/Australian clade far from melon (C. melo). BMC Evol. Biol., 11, 1-11

Sadiq G.A., Omerkhil N., Zada K.A. and Safdary A.J. (2019). Evaluation of growth and yield performance of five cucumbers (Cucumis sativus L.) genotypes: Case study Kunduz Province, Afghanistan. Int. J. Adv. Edu. Res., 4 (6), 22-28

Strefeler M.S. and Wehner T.C. (1986). Estimates of heritabilities and genetic variances of three yield and five quality traits in three fresh-market cucumber populations. J. Amer. Soc. Hort. Sci., 111 (4), 599-605

Uguru M.I. (1998). Traditional conservation of vegetable cowpea in Nigeria. Genetics Resour. Crop Evol., 45, 135-138

Vimala P., Ting C.C., Salbiah H., Ibrahim B. and Ismail L. (1999). Biomass production and their effects on the yield of cucumber. J. Trop. Agric. Food Sci., 27, 47-55

Wehner T.C. and Cramer C.S. (1996). Ten cycles of recurrent selection for fruit yield, earliness and quality in three slicing cucumber populations. J. Am. Soc. Hort. Sci., 121 (3), 362-366 